\title{
Development of a system of indicators of water supply efficiency and productivity
}

\author{
Dmitriy Serov ${ }^{1, *}$ \\ ${ }^{1}$ Peter the Great St. Petersburg Polytechnic University, 195251, Polytechnicheskaya, 29, \\ St.Petersburg, Russia
}

\begin{abstract}
The article describes the structure of the water supply process. The importance of a value-oriented approach to water supply is substantiated. The classification of directions for evaluating the efficiency and productivity of water supply has been developed. A comprehensive system of indicators of water supply efficiency and productivity is proposed. It is shown that it is advisable to use a system of indicators of efficiency and productivity, which is developed taking into account the specifics of the value chain, to evaluate the company's performance. This system of indicators reflects different aspects - resource, technological, financial and economic, consumer, etc. Based on the system of indicators of efficiency and productivity, it becomes possible to qualitatively analyze the balance and proportionality, quality, resource sufficiency and security, the level of manufacturability of the water supply process, as well as the degree of customer satisfaction.
\end{abstract}

\section{Introduction}

Adequate and reliable assessment of water utilities ' performance is put forward in modern conditions as one of the most important tasks for improving water supply management $[1,2]$. The task requires a comprehensive approach. The relevance of this assessment is due to the system of contradictions faced by Russian water utilities. Here it is worth noting the following main contradictions:

1. Depreciation and low technical and technological level of fixed assets requires attracting external investment. But in this case, the investment component in the tariff increases significantly (with existing restrictions on their growth and the possibility of compensating for the growth of tariffs at the expense of local budgets). This circumstance imposes high requirements for evaluating the financial and economic activities of water utilities.

2. getting an effect at one technological stage may not lead to an increase in the productivity and efficiency of the entire value chain due to the inefficiency of other stages. For example, leaks and unrecorded water consumption, which make up $22.7 \%$ of all water supplied to the network. But according to expert estimates, the average water loss is at least $40 \%$. Reconstruction of treatment facilities with such losses in the water supply network is

\footnotetext{
* Corresponding author: swchirokov@mail.ru
} 
necessary. Accordingly, new water treatment costs increase in proportion to losses in the water supply network. This inflates the cost of providing the service and requires an increase in tariffs or subsidies.

3. Market requirements to ensure the profitability of current activities and return on investment costs conflict with social restrictions and the corresponding state social policy.

The above and other factors determine the importance of evaluating productivity and efficiency. This is necessary from the point of view of optimizing the current activities of water utilities, as well as the validity of investment projects for development.

\section{Materials and methods}

The structure of the water supply process. In methodological terms, performance reflects the key cause-and-effect relationships in the functioning of the object. At the same time, it is important to rely on the basic principles of the dialectical approach. As Hegel points out, "of the three points of the process of necessity-the condition, the object, and the activity -

a. Conditions. Are used as material for the subject and, therefore, are included in the content of the subject.

b. The Object. Through the use of conditions ... obtains its external existence, realizes its meaningful definitions, which in turn correspond to the conditions, so that it turns out that the object is produced by the conditions and owes them their definitions.

C. Activities. It is a movement that translates conditions into an object and the latter into conditions as a sphere of existence, or rather, a movement that deduces an object from the conditions in which it exists in itself, and gives the object existence by removing the existence that the conditions possess" [3].

In applied terms, "conditions" are the raw materials and resources of the enterprise. "Activity" - the technological chain of product creation (from the initial raw material to the final product for a specific object). The "item" is the actual product at various technological stages. In this case, the product of the previous technological stage acts as the initial raw material for the subsequent technological stage. The main technological stages of the water supply process include water intake from the water supply source (water intake), preparation of drinking water (water treatment), transportation of water to the consumer through water supply networks using booster pumping stations, and transfer of treated water to the consumer for further consumption [4].

Schematically, this relationship of all the "three points" of the water supply enterprise can be represented as follows:

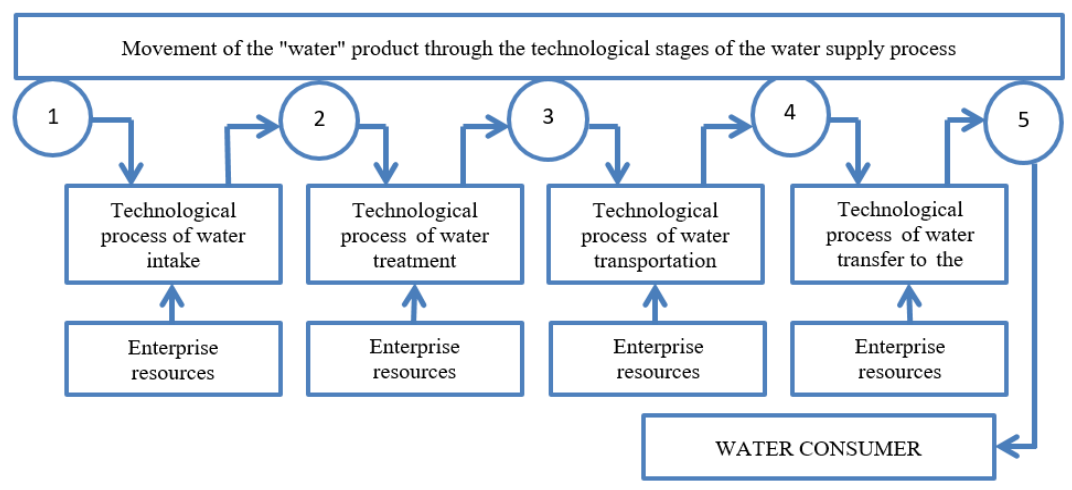

Fig. 1. Interrelation of production components of water supply enterprise functioning. 
Description:

- qualitative state of water when driving across the stages of supply: 1 - raw materials: water entering the water intake from a water supply source; 2 - finished: water received for treatment; 3 - finished water entering the water network for transporting; 4 prefabricated water after transportation; 5 - the final product: the water supplied to the consumer for future consumption.

Based on the methodological approach taken as a basis, we will consider the basic concepts of enterprise performance.

\section{Approach developed}

Classification of directions for evaluating water supply efficiency and productivity indicators. In economic theory, efficiency is defined as:

- the ratio of the result to the effort expended;

- relationship between the result achieved and the resources used;

- the ratio between the achieved result and the resources used.

It is proposed to distinguish the following types of water supply efficiency: General, resource and technological efficiency [5],

Overall efficiency

The overall efficiency of water supply is determined by the ratio of the final product and the total cost of obtaining it, usually in cost terms. Unfortunately, the scientific literature allows for a mix of performance and efficiency. In relation to the current activity of the enterprise, it is primarily a question of comparing revenue and total costs, as a result, the overall economic efficiency is most fully reflected by the indicators of profit (absolute indicator) and profitability (relative indicator):

- the ratio of results and costs in absolute terms is, in fact, the resulting economic effect (the difference between the result and costs in terms of value);

- profitability in relative terms can be considered as the ratio of profit (effect) to costs (ROI) or to the result "revenue" (ROI).

In the field of investment activity of an enterprise, when justifying investments, such estimated performance indicators as net cash flow, payback period, and marginal rate of return are used, for example. At the same time, the result is a positive cash flow.

Technological efficiency

Technological efficiency is determined for a specific technological stage by comparing the intermediate or final result with the total cost (the cost of all resources) at this technological stage. In the first case, we are talking about local technological efficiency, in the second-about the overall technological efficiency.

Resource efficiency

The next level of evaluation of water supply efficiency is resource efficiency as a comparison of the intermediate or final result with the costs of a specific resource at the appropriate technological stage. This efficiency is calculated for specific types of resources (personnel, fixed assets and equipment, materials and reagents, electricity, water networks, etc.). for Example, energy efficiency indicators are calculated for energy, specific resource consumption for materials and reagents, etc.

When measuring resource efficiency, there are two ways to evaluate it:

a) Local resource efficiency at a specific technological stage of water supply (comparison of the intermediate result of the technological stage with the costs of a specific resource at this stage). For example, the cost of electricity for the treatment of $1 \mathrm{~m} 3$ of water, the labor productivity of personnel engaged in water treatment, etc. 
b) Resource efficiency throughout the value chain (comparing the final product with the costs of a specific resource at all technological stages).

Table 1. Technological efficiency of water supply.

\begin{tabular}{|c|c|c|c|c|}
\hline & semiproduct 1 & semiproduct 2 & semiproduct 3 & final product \\
\hline Cost & $\begin{array}{l}\text { Water coming in } \\
\text { for treatment }\end{array}$ & $\begin{array}{c}\text { Water entering the } \\
\text { water supply } \\
\text { network }\end{array}$ & $\begin{array}{l}\text { Water after } \\
\text { transportation }\end{array}$ & $\begin{array}{l}\text { Water supplied to } \\
\text { the consumer }\end{array}$ \\
\hline $\begin{array}{l}\text { The cost of } \\
\text { water intake }\end{array}$ & $\begin{array}{c}\text { ratio of semi- } \\
\text { finished product } \\
\text { parameters } 1 \text { and } \\
\text { water intake costs }\end{array}$ & & & \\
\hline $\begin{array}{l}\text { The cost of } \\
\text { cleaning the } \\
\text { water }\end{array}$ & & $\begin{array}{l}\text { ratio of semi- } \\
\text { finished product } \\
\text { parameters } 2 \text { and } \\
\text { water treatment } \\
\text { costs }\end{array}$ & & \\
\hline $\begin{array}{l}\text { The cost of } \\
\text { transporting } \\
\text { water }\end{array}$ & & & $\begin{array}{c}\text { ratio of semi- } \\
\text { finished product } \\
\text { parameters } 3 \text { and } \\
\text { water transportation } \\
\text { costs } \\
\end{array}$ & \\
\hline $\begin{array}{l}\text { Water } \\
\text { transfer costs } \\
\text { to the } \\
\text { consumer }\end{array}$ & & & & $\begin{array}{l}\text { the ratio of } \\
\text { parameters of the } \\
\text { final product and } \\
\text { the cost of } \\
\text { transferring water } \\
\text { to the consumer }\end{array}$ \\
\hline $\begin{array}{l}\text { Total costs } \\
\text { for all } \\
\text { technological } \\
\text { stages of } \\
\text { water supply }\end{array}$ & \multicolumn{4}{|c|}{$\begin{array}{l}\text { Total technological efficiency of water supply: the ratio of parameters of the final } \\
\text { product and total costs for all technological stages of water supply }\end{array}$} \\
\hline
\end{tabular}

For example, the specific electrical capacity of the final product (electricity costs per $1,000 \mathrm{~m} 3$ of water supplied to the consumer), the productivity of the company's personnel, and so on.

At the same time, the cost of resources and the intermediate/final product can be estimated in natural (number of personnel, $\mathrm{kWh}$ of electricity, $\mathrm{m} 3$ of water, etc.) and cost (staff payroll, electricity costs, revenue from water sales, etc.) indicators. Depending on the type of resource, resource efficiency can acquire an "independent sound". For example, energy efficiency is highlighted (table 2).

Resource efficiency is associated with a reduction in resource consumption per result unit. The downside of this is reduced resource requirements (resource savings). For example, increasing labor productivity reduces the labor intensity of production and reduces the need for personnel and allows you to produce more product with the same number of employees. Therefore, we can talk about the cost-effective use of resources. If productivity is the amount of output produced per unit of time a resource is used, then costeffectiveness is determined by simply comparing the resources that were intended to be used to achieve certain goals and perform work with the resources that were actually consumed.

There are the following dependencies between technological and resource efficiency:

- the sum of costs for all resources for a specific technological stage of water supply gives the total costs for this technological stage (for calculating local technological efficiency);

- the sum of costs for all resources for all technological stages of water supply gives the total costs for all technological stages (for calculating the overall technological efficiency). 
Therefore, resource efficiency affects local and overall technological efficiency (through resource costs). In turn, technological efficiency affects the final result (through the ratio of intermediate and final products), respectively-affects the overall efficiency of the enterprise.

Table 2. Resource efficiency of water.

\begin{tabular}{|c|c|c|c|c|}
\hline & semiproduct 1 & semiproduct 2 & semiproduct 3 & final product \\
\hline $\begin{array}{c}\text { Costs of a } \\
\text { specific resource }\end{array}$ & $\begin{array}{l}\text { Water coming } \\
\text { in for } \\
\text { treatment }\end{array}$ & $\begin{array}{c}\text { Water entering } \\
\text { the water supply } \\
\text { network }\end{array}$ & $\begin{array}{l}\text { Water after } \\
\text { transportation }\end{array}$ & $\begin{array}{c}\text { Water } \\
\text { supplied to } \\
\text { the consumer }\end{array}$ \\
\hline $\begin{array}{l}\text { Resource costs } \\
\text { to the water } \\
\text { intake }\end{array}$ & $\begin{array}{l}\text { ratio of semi- } \\
\text { finished } \\
\text { product } \\
\text { parameters } 1 \\
\text { and resource } \\
\text { costs } \\
\end{array}$ & & & \\
\hline $\begin{array}{l}\text { Resource costs } \\
\text { for water } \\
\text { treatment }\end{array}$ & & $\begin{array}{l}\text { ratio of semi- } \\
\text { finished product } \\
\text { parameters } 2 \\
\text { and resource } \\
\text { costs }\end{array}$ & & \\
\hline $\begin{array}{l}\text { Resource costs } \\
\text { for water } \\
\text { transportation }\end{array}$ & & & $\begin{array}{l}\text { ratio of semi- } \\
\text { finished product } \\
\text { parameters } 3 \text { and } \\
\text { resource costs }\end{array}$ & \\
\hline $\begin{array}{l}\text { Resource costs } \\
\text { for transferring } \\
\text { water to the } \\
\text { consumer }\end{array}$ & & & & $\begin{array}{l}\text { the ratio of the } \\
\text { final product } \\
\text { and the cost of } \\
\text { the resource }\end{array}$ \\
\hline $\begin{array}{l}\text { Total resource } \\
\text { costs for all } \\
\text { technological } \\
\text { stages of water } \\
\text { supply }\end{array}$ & \multicolumn{4}{|c|}{$\begin{array}{l}\text { Total resource efficiency: the ratio of final product parameters and total } \\
\text { resource costs for all technological stages of water supply }\end{array}$} \\
\hline
\end{tabular}

When considering the impact of water supply.

From a methodological point of view, it is advisable to transform the "object" (in the Hegelian sense) into a "result". The scientific literature correctly emphasizes the fact that the result expresses causal relationships:

- result-consequence of a chain (sequence) of actions or events expressed qualitatively or quantitatively;

- result - what is received at the end of some activity, work, result.

For example, the material result of an enterprise's activity should be a product. In this case, the result of an enterprise's activity can be intermediate (the result of a specific technological stage) and final (the result transmitted to an external consumer).

Thus, the intermediate results are semi-finished products obtained at different technological stages of water supply:

- water entering the water intake from the water supply source;

- water received after water intake for treatment;

- water entering the water supply network for transportation after cleaning;

- water delivered to the consumer after transportation.

The end result in our example is the product that is passed to the consumer (water that is delivered to the consumer for subsequent consumption). 
The derivative of "result" is " performance. The literature on this issue has the following points of view:

- performance is the achievement of a goal while maintaining the set limits and various resources, such as time;

- performance - the ratio of the actual result (measured indicator - the so-called "performance criterion") to the planned.

As can be seen from these definitions, performance is usually reduced to assessing the dynamics of changes by comparing the actual level with the target, planned, normative, etc. This approach is particularly clearly reflected in the standards of the GOST R ISO 9000 series. In these documents, for example, performance is defined as "the degree to which planned activities are implemented and planned results achieved" [6]. In the scientific literature, it is customary to distinguish between "productivity" and "efficiency". However, this understanding of the differences between" performance "and" efficiency " has a significant drawback, which is as follows. To evaluate performance or productivity, you need to have a clearly defined "reference point": goals, standards, plan, previous data, competitor data, best practices, and so on. In the above definitions of performance and efficiency, this " right "is for some reason" assigned " exclusively to performance. But the dynamics of the result-cost ratio can also be evaluated when comparing the fact with the plan, previous period, target or normative values, etc. [7].

In our opinion, this is not correct, since in this case we have the same result, only set by the goal (the so-called target result). And the degree of achievement of the goal only sets the criteria for evaluating such a result. In addition, with the proposed "target efficiency", the achievement of the result (goal) is not linked to the costs necessary for this.

Thus, the traditionally understood difference between performance and efficiency is not a difference at all, but, on the contrary, "General" possible ways to assess dynamics. Therefore, the task of determining the fundamental difference between performance and efficiency cannot be considered completed. It is also relevant because performance can increase against the background of falling efficiency (and Vice versa). We also note that the result can be either positive or negative. Hence, by the way, the phrase "a negative result is also a result became widely used.

If we talk about performance, it is also possible to distinguish between technological and value performance.

Technological performance

In our opinion, the comparison of results should initially be carried out not in the plane of "fact-plan", "fact-previous period", "fact - goal", "fact - standard", but in the context of the movement (reproduction) of the result itself. In other words, within the product value chain $[8,9]$. Thus, performance is based on a comparison of performance results. In other words, the intermediate and final results are compared:

- input processed resource and semi-finished product 1 ;

- semi-finished product 1 and semi-finished product 2 ;

- semi-finished product 2 and semi-finished product $\mathrm{N}$;

- semi-finished product $\mathrm{N}$ and final product.

In the proposed approach, performance reflects the development of the result (the transition of the result from one qualitative state to another) in the process of creating value. Here it is appropriate to give the following statement of dialectical logic: "every beginning is an undeveloped result, and the result is a developed beginning". Similarly, first there is an undeveloped intermediate result, then there is a movement from an undeveloped intermediate result to a more developed intermediate result, and finally there is an expanded beginning, that is, the final result [7]. 
An illustration of the proposed approach to water performance (using the example of volumetric parameters of the result) is shown in table 1 . here you should provide a few explanations:

1) the Initial processed raw material (in our example, water from a water supply source) acts as a kind of initial product (initial semi - finished product), with which the further intermediate product (semi-finished product 1) is compared.

2) performance Assessment necessarily involves a quantitative assessment. For example, the level of water losses at each technological stage of water supply can be determined in absolute terms (by comparing "input" and "output" process steps) or in relative terms (percentage of the volume of water at the entry process steps).

3 ) it Is most practical to consistently compare products at the junction of "neighboring" technological stages when evaluating performance. In this case, the result at the "output" of the previous technological stage acts as the initial processed raw material for the subsequent technological stage and is compared with the result of this stage (the so-called "chain" method). Since there is a technological process (a specific technological stage) between the products, this actually means evaluating the local performance of the technological process. Therefore, such performance is properly called technological or functional [10-14].

In this case, performance means "get the maximum result for a given incoming result".

However, you can also compare the results for" non-neighboring " technological stages. In this case, the overall performance can be evaluated by comparing the initial processed raw material with the final product (the so-called output of the final product per unit of incoming raw material processed). For example, water consumption at a water intake per unit volume of water transferred to the consumer.

4) In the General case, process efficiency is assessed via the loss of water and the required water parameters at all technological stages of water supply (table 3).

5) Naturally, the results of comparing intermediate and final products can be further evaluated in the coordinate system "fact-plan", "fact-previous period", "fact-goal", "factstandard", etc.

Table 3. Technological efficiency of water supply.

\begin{tabular}{|c|c|c|c|c|}
\hline \multicolumn{5}{|c|}{ Movement of the "water" product through the technological stages of the water supply process } \\
\hline $\begin{array}{l}\text { raw materials to } \\
\text { be processed }\end{array}$ & $\begin{array}{l}\text { raw materials to } \\
\text { be processed } 1\end{array}$ & $\begin{array}{l}\text { raw materials to } \\
\text { be processed } 2\end{array}$ & $\begin{array}{l}\text { raw materials to } \\
\text { be processed } 3\end{array}$ & product \\
\hline $\begin{array}{l}\text { Technological } \\
\text { stage " water } \\
\text { intake»» }\end{array}$ & $\begin{array}{l}\text { Technological } \\
\text { stage " water } \\
\text { intake» }\end{array}$ & $\begin{array}{l}\text { Technological } \\
\text { stage " water } \\
\text { treatme }\end{array}$ & $\begin{array}{l}\text { Technological } \\
\text { stage " water t } \\
\text { ransportation»" }\end{array}$ & $\begin{array}{l}\text { Technological } \\
\text { stage " water } \\
\text { transfer to the } \\
\text { consumer» }\end{array}$ \\
\hline $\begin{array}{l}\text { Water from a } \\
\text { water supply } \\
\text { source }\end{array}$ & $\begin{array}{l}\text { Water coming in } \\
\text { for treatment }\end{array}$ & $\begin{array}{l}\text { Water entering } \\
\text { the water supp }\end{array}$ & $\begin{array}{l}\text { Water after } \\
\text { transportation }\end{array}$ & $\begin{array}{l}\text { Water supplied } \\
\text { to the cons }\end{array}$ \\
\hline \multicolumn{5}{|c|}{$\begin{array}{l}\text { Level of water loss during water } \\
\text { intake }\end{array}$} \\
\hline & \multicolumn{2}{|c|}{ Level of water loss during cleaning } & & \\
\hline & & \multicolumn{2}{|c|}{$\begin{array}{l}\text { Level of water loss in the water } \\
\text { supply network }\end{array}$} & \\
\hline & & & \multicolumn{2}{|c|}{$\begin{array}{l}\text { Level of water loss during } \\
\text { transmission to the consumer }\end{array}$} \\
\hline Overall perfor & $\begin{array}{l}\text { of water supp } \\
\text { water loss fron }\end{array}$ & $\begin{array}{l}\text { parison of ra } \\
\text { intake to tran }\end{array}$ & $\begin{array}{l}\text { terials and final pi } \\
\text { to the consumer. }\end{array}$ & luct: the level of \\
\hline
\end{tabular}


The performance of the conformity of the product (service) to the user's values.

The end of the value creation process is the receipt of the final product and its consumption by the consumer (or the evaluation of the product by the consumer). This is also the end result of this process. Therefore, performance, in addition to the approach discussed above, can be considered by comparing the end product transferred to the consumer with the requirements of the consumer [15].

In this regard, from the point of view of the company's activities, it is of undoubted practical interest to use elements of a value-based approach to evaluating performance. In the most General form, the value-oriented approach is understood as the orientation of the enterprise's activity on the consumer's values - on their identification and effective production of goods/services in accordance with the consumer's values.

Consumer values act as a kind of "bridge" between the needs and parameters of the product and service. Therefore, they are the basis for the formation of any market (commercial) turnover of goods and services.

"Values" characterize the key (significant) requirements of the consumer to meet their needs when consuming goods and services, and, consequently, - based on the values, the characteristics (properties and quality) of the product or service that are significant for the consumer are determined. In other words, "value for the consumer" is what is significant in meeting the needs of the consumer, based on which parameters he estimates the degree of satisfaction of his needs [16].

In relation to water supply, the main values of the consumer and their corresponding water supply parameters are shown in table 4 .

Table 4. Consumer values and value parameters of water supply.

\begin{tabular}{|c|l|l|}
\hline № & \multicolumn{1}{|c|}{$\begin{array}{c}\text { Values } \\
\text { consumer }\end{array}$} & Value parameters of water supply \\
\hline 1 & Providing water in the required & Volume of water \\
\hline 2 & Providing water with the necessary pressure & Water pressure \\
\hline 3 & Water supply 24 hours a day & Continuity/water supply mode \\
\hline 4 & Providing water of the requi & Water quality \\
\hline 5 & $\begin{array}{l}\text { Providing water at affordable rates } \\
\text { (availability of tariffs) and transparency of } \\
\text { payments }\end{array}$ & $\begin{array}{l}\text { Cost of water supply (tariffs for } \\
\text { water and services) }\end{array}$ \\
\hline
\end{tabular}

Value performance (the level of customer value assurance, service quality, and customer satisfaction) is evaluated in terms of value. In this case, the indicators that characterize the consumer's values are taken as evaluation indicators.

\section{Results}

Formation of a system of indicators of water supply efficiency and productivity. Classification of areas for evaluating efficiency and productivity allows you to develop a system of appropriate indicators for water supply [17]. 
Table 5. Indicators of water supply efficiency and productivity.

\begin{tabular}{|c|c|c|c|}
\hline № & $\begin{array}{c}\text { Areas of activity } \\
\text { assessment }\end{array}$ & Subgroups & Indicators \\
\hline \multirow[b]{2}{*}{1} & \multirow{2}{*}{$\begin{array}{l}\text { Result } \quad \text { of } \\
\text { activity }\end{array}$} & Natural-real resul & Volume of supplied water, m3 \\
\hline & & Financial and econ & Revenue \\
\hline 2 & Productivity & & \\
\hline 2.1 & $\begin{array}{l}\text { Technological } \\
\text { performance }\end{array}$ & & $\begin{array}{l}\text { Percentage of unrecorded water expenses and losses during } \\
\text { transportation }\end{array}$ \\
\hline \multirow{3}{*}{2.2} & \multirow{3}{*}{$\begin{array}{l}\text { Productivity in } \\
\text { matching the } \\
\text { product (service) } \\
\text { to the } \\
\text { consumer's } \\
\text { values }\end{array}$} & $\begin{array}{l}\text { Conformity of the } \\
\text { service to the } \\
\text { consumer's values }\end{array}$ & $\begin{array}{l}\text { Customer satisfaction (based on survey results): } \\
\text { - cold water quality; } \\
\text { - uninterrupted water supply; } \\
\text { - the pressure of the incoming water; } \\
\text { - the smell of incoming water; } \\
\text { - cold water color; } \\
\text { - water transparency; } \\
\text { - taste of cold water; } \\
\text { - operation of the " Hotline»; } \\
\text { - tariffs for cold water supply; } \\
\text { - providing notification information about repair work } \\
\text { schedules and the resumption of water supply } \\
\text { Average waiting time for a connection with «a Hotline } \\
\text { operator» }\end{array}$ \\
\hline & & $\begin{array}{l}\text { Water pressure and } \\
\text { continuity of water } \\
\text { supply }\end{array}$ & $\begin{array}{l}\text { - the number of registered and justified complaints about } \\
\text { reduced cold water pressure } \\
\text { - the number of interruptions in the water supply that occurred } \\
\text { as a result of accidents, damages and other technological } \\
\text { violations; } \\
\text { - maximum duration of disconnecting consumers from } \\
\text { providing water supply services }\end{array}$ \\
\hline & & $\begin{array}{l}\text { Compliance with } \\
\text { water supply } \\
\text { standards }\end{array}$ & $\begin{array}{l}\text { - compliance of drinking water quality at the outlet of water } \\
\text { supply stations with regulatory requirements, \%; } \\
\text { - compliance of drinking water quality in the distribution } \\
\text { water network with regulatory requirements; } \\
\text { - the share of drinking water samples supplied from water } \\
\text { sources that do not meet the established requirements in the } \\
\text { total volume of samples, } \% \text {; } \\
\text { - the percentage of drinking water samples in the distribution } \\
\text { water network that do not meet the established requirements } \\
\text { in the total volume of samples, } \%\end{array}$ \\
\hline \multirow{2}{*}{3} & \multirow{2}{*}{$\begin{array}{l}\text { Result } \\
\text { activity }\end{array}$} & Natural-real resul & Volume of supplied water, m3 \\
\hline & & Financial and econ & Revenue \\
\hline 4 & Efficiency & & \\
\hline \multirow[b]{2}{*}{4.1.} & \multirow{2}{*}{$\begin{array}{l}\text { Overall } \\
\text { efficiency }\end{array}$} & Absolute figure & Profit \\
\hline & & Relative indicator & $\begin{array}{l}\text { Value for money } \\
\text { Profitability of sales }\end{array}$ \\
\hline \multirow{2}{*}{4.2 . } & \multirow{2}{*}{$\begin{array}{l}\text { Technological } \\
\text { efficiency }\end{array}$} & General & $\begin{array}{l}\text { The ratio of the volume of water supplied to the consumer to } \\
\text { the costs at all technological stages of water supply }\end{array}$ \\
\hline & & Local & $\begin{array}{l}\text { The ratio of the volume of processed water at a specific } \\
\text { technological stage of water supply to the cost of this stage }\end{array}$ \\
\hline \multirow{5}{*}{4.3 . } & \multirow{5}{*}{$\begin{array}{l}\text { Resource } \\
\text { efficiency }\end{array}$} & Staff & Labour productivity \\
\hline & & Fixed assets & $\begin{array}{l}\text { Capital productivity } \\
\text { Productivity of equipment } \\
\text { Indicator of the use of production facilities (by volume of } \\
\text { pumping) in relation to the peak day of the reporting year }\end{array}$ \\
\hline & & $\begin{array}{l}\text { Materials and } \\
\text { reagents }\end{array}$ & $\begin{array}{l}\text { Consumption per } 1,000 \mathrm{~m} 3 \text { of supplied water or } 1 \text { million } \\
\text { rubles of revenue }\end{array}$ \\
\hline & & Electricity & $\begin{array}{l}\text { Consumption }(\mathrm{kWh}) \text { per } 1,000 \mathrm{~m} 3 \text { of water supplied or } 1 \\
\text { million rubles of revenue }\end{array}$ \\
\hline & & $\begin{array}{l}\text { Water supply } \\
\text { network }\end{array}$ & The number of damages per $10 \mathrm{~km}$. water supply network \\
\hline
\end{tabular}




\section{Conclusions}

Based on the above classification of indicators of water supply efficiency and productivity, primary information is collected, dynamics of changes in indicators are evaluated, dependencies between different indicators are identified, and the main cause-and-effect relationships are analyzed for further development of neutralizing, corrective or preventive measures.

Thus, it is advisable to use a system of indicators of efficiency and productivity, developed taking into account the specifics of the value chain, to evaluate the company's performance. This system of indicators reflects different aspects - resource, technological, financial and economic, consumer, etc. In General, based on the system of performance indicators, it becomes possible to qualitatively analyze the balance and proportionality, quality, resource sufficiency and security, the level of manufacturability of the water supply process, as well as the degree of customer satisfaction.

\section{References}

1. T.S. Nagornaya, Improving the management methodology of operating companies in the field of housing and communal services, Young scientist 20, 260-262 (2017) URL https://moluch.ru/archive/154/43556. (In Russian)

2. A.E. Saak, E.V. Pahomov, V.N. Tyushnyakov, Information technologies management: Textbook for universities (2nd edn., Saint Petersburg, "Piter" Publishing House, 2012)

3. G.V.F. Gegel, Encyclopedia of philosophical Sciences, Science of logic 1, 452 (1974)

4. I.V. Karnatsevich, G.G. Bikbulatova, K.V. Ryapolov, Prospects for the genetic method of calculation of the basic flow at daily intervals, Omsk scientific Bulletin. Series 1, The Resources Of The Earth. The Human 1(104), 224-231 (2011)

5. IInformation technologies in the sphere of housing and communal services, Krasnoyarsk economic forum 2017, http://www.aetp.ru/news/item/410261 (In Russian)

6. GOST R ISO 9000-2008 Quality Management Systems. Main provisions and vocabulary (2015) (In Russian)

7. A.R. Saitgaraev, G.A. Gareeva, D.R. Grigor'eva, Efficiency of using information technologies in the Russian economic system, Young scientist 28, 526-529 (2016) https://moluch.ru/archive/132/36970. (In Russian)

8. Digitalization in the field of housing and communal services, https://www.osp.ru/cw/2017/10/13052377. (In Russian)

9. Digital housing and communal services: is it easy to implement the President's plans?, http://www.iksmedia.ru/blogs/post/5398071-Czifrovoe-ZHKX-legko-lirealizovat.html. (In Russian)

10. D.V. Gorbachev, E.G. Hakimova, Overview of modern information technologies for business automation in the field of housing and communal services, Young scientist 13, 33-35 (2015) https://moluch.ru/archive/93/20566. (In Russian)

11. M.V. Bolsunovskaya, S.V. Shirokova, A.V. Loginova, M.B. Uspenskiy, The development and application of non-standard approach to the management of a pilot project. Proc. 2nd International Scientific Conference on Digital Transformation on Manufacturing, Infrastructure and Service (DTMIS 2018), St. Petersburg, 2018, DOI: 10.1088/1757-899X/497/1/012024. 
12. Innovations and new technologies in the field of housing and communal services, https://www.rc-online.ru/about/smi/innovatsii-i-novye-tekhnologii-v-sfere-zhkkh. (In Russian)

13. A.E. Parshkov, Information technologies and their application in the field of housing and communal services, Technic. Technologies. Engineering 1, 14-17 (2018) https://moluch.ru/th/8/archive/76/3012. (In Russian)

14. V.V. Chaadaeva, Information technologies in enterprises' management in the field of housing and communal services, New science: Strategies and vectors of development 3-1 (70), 250 (2016)

15. A.N. Pavlov, "Geoinformation system of housing and communal services" and "The Reform of housing and communal services" - new steps to Informatization of the housing and utilities sector in Russia]. Proc. of the 6th Intern. Scientif. Conf. Problems and prospects of economy and management, St. Petersburg, 222-225 (2017) URL https://moluch.ru/conf/econ/archive/263/13269. (In Russian)

16. A.S. Makarov, M.V. Bolsunovskaya, S.V. Shirokova, M.B. Uspenskij, A.A. Kuz'michjov, Proc. Int. Conf. SCM-2018 61-64 (2018)

17. V.N. Volkova, A.A. Denisov, Systems theory and systems analysis: textbook, 2nd edn., (2017) (In Russian) 